\title{
DEBUS BANTEN: \\ Pergeseran Otentisitas dan Negosiasi \\ Islam-Budaya Lokal
}

\author{
Kiki Muhamad Hakiki ${ }^{1}$ \\ IAIN Raden Intan Lampung \\ m_hakiki@yahoo.com
}

\begin{abstract}
Abstrak
Sebagai suatu produk budaya, kesenian debus merepleksikan kompleksitas manusia itu sendiri. Di dalamnya terdapat kepentingan sosial, politik, bahkan nilai-nilai religi. Dalam historisitasnya debus mengalami pasang surut khususnya ketika berhadapan dengan perkembangan zaman dan nilai kelokalan. Artikel ini mengkaji apakah kesenian debus telah mengalami perubahan atau dengan kata lain terpengaruh oleh budaya lokal atau tidak. Hasil penelitian menemukan fakta bahwa kesenian debus nampaknya sudah mengalami pergeseran dan perubahan karena ia harus menyesuaikan diri agar tak ketinggalan zaman atau bahkan dilupakan. Kesenian debus saat ini sudah mengalami modifikasi yang ditunjukkan dengan banyak sekali hal-hal yang tak pernah dipraktekkan pada debus tempo dulu. Debus saat ini telah meninggalkan atau lepas dari asalnya yakni tarekat. Pergeseran itu terlihat dari segi ritual, gaya pertunjukan, pola perekrutan personil dan tujuan yang ingin dicapai. Kesenian debus sekarang lebih cenderung digunakan sebagai alat hiburan masyarakat atau menjadi komoditi pariwisata saja ketimbang sebagai suatu produk budaya yang mengandung nilai keagamaan.
\end{abstract}

Abstrak

DEBUS BANTEN: SHIFTING OF AUTHENTICITY AND NEGOTIATIONS BETWEEN ISLAM AND LOCAL CULTURE. As a product of culture, Debus

${ }^{1}$ Staf Pengajar Fakultas Ushuluddin IAIN Raden Intan Lampung. Menyelesaikan studi S3 Program Religious Studies di UIN Sunan Gunung Djati Bandung. 
attraction reflects human complexity. It has sociio-political interests and even religious values. In its historicity, Debus has undergone its ups and downs, especially when dealing with the times and the local values. This article examines whether or not the Debus arts has changed, or, in other words, has been affected by the local culture. This study finds out that Debus art seems to have experienced a shift or change because it had to adjust to be not outdated or even forgotten. Debus art today has been modified as indicated by a lot of things that never been practiced in the past. Debus has now left his home or been separated from its origin namely the tarekat. The shift can be traced in several aspects, including terms of ritual, show style, personnel recruitment pattern and goals to be achieved. Debus arts are now more likely to be used as a tool of public entertainment or just a a tourism commodity, rather than as cultural products that contain religious values.

Kata Kunci: Debus Banten; Otentisitas; Komodifikasi; Politik Kebudayaan.

\section{A. Pendahuluan}

Setiap daerah di Indonesia mempunyai budaya yang menggambarkan kekhasan daerah masing-masing termasuk juga di dalamnya Banten, ${ }^{2}$ daerah yang berada paling barat ujung pulau Jawa, dikenal sebagai kota santri dan kota jawara atau pendekar. ${ }^{3}$ Sejarah mencatat, pada awal abad 19, Banten dijadikan rujukan oleh para ulama di Nusantara, bahkan di Asia Tenggara, tentang keislaman (ilmu Islam).

Menurut Snouck Houergronje, masyarakat Banten pada saat itu sudah sadar dalam menjalankan syariat Islam, jika dibandingkan dengan masyarakat Jawa pada umumnya, Snouck mencontohkan seperti dalam pengamalan ibadah puasa dan zakat yang dipraktekkan masyarakat Banten. ${ }^{4}$

Ragam seni pertunjukan kesenian rakyat Banten, pada umumnya berkembang secara turun-temurun, yang tidak terlepas dari nafas keagamaan serta dalam perjalanannya tidak terlepas

${ }^{2}$ Daerah Banten pada awalnya termasuk daerah yang masuk wilayah provinsi Jawa Barat. Kini Banten telah resmi menjadi provinsi yang mandiri.

${ }^{3}$ Halwani Mihrob, "Fase, Dampak dan Perwujudan Dalam Budaya Islam", dalam Aswab Mahasin (et.al ), Ruh dalam Budaya Bangsa, (Jakarta : Festival Istiqlal II, 1996), hlm. 145.

${ }^{4}$ Martin Van Bruinessen, Kitab Kuning, Pesantren dan Tarekat, (Bandung: Mizan, 1999), hlm. 153. 
dari pengaruh agama Islam, maupun agama lain. Kesenian rakyat yang berkembang di Banten hingga sampai sekarang sangatlah beragam, satu di antaranya yang sangat fenomenal sampai kini adalah seni debus.

Sebagai hasil budaya, debus merupakan kompleksitas manusia itu sendiri. Di dalamnya terdapat kepentingan, sosial, politik, bahkan religi. Secara historis keberadaan debus tidak terlepas dari nafas Islam. Namun dalam perjalanannya debus mengalami pergeseran khususnya ketika berhadapan dengan perkembangan zaman dan nilai-nilai lokal Banten. Oleh karena itu, artikel ini akan mengkaji lebih lanjut tentang debus Banten. Apakah kesenian khas Banten yang disebut dengan debus ini terhindar dari pengaruh budaya lokal, atau tidak, atau apakah ia tidak mengalami perubahan-perubahan?.

\section{B. Mengenal Debus Banten}

Apa itu debus ?. Sampai saat ini para peneliti masih memperdebatkan tentang definisi yang pasti dari istilah "debus". Pengertian mengenai debus sangat bervariasi, di antaranya ada yang berpendapat bahwa istilah debus berasal dari bahasa Arab yaitu "Dabbas" yang berarti sepotong besi yang runcing yang dianalogikan dengan jarum. ${ }^{5}$ Ada yang berpendapat istilah debus berasal dari kata sebuah benda yaitu "Al Madad", yaitu besi runcing seperti paku besar. ${ }^{6}$ Selain itu ada yang mengatakan bahwa debus berasal dari bahasa Persia, yang dalam bahasa Indonesia diartikan dengan "tusukan". ' Sedangkan menurut Tb. A Sastra Suganda yang pernah menjabat sebagai kepala Dinas Kebudayaan Serang mengatakan, bahwa debus berasal dari kata "tembus". Hal ini dapat dilihat dari alat yang digunakan dalam permainan debus, yaitu benda tajam yang apabila ditusukkan ke tubuh akan dipastikan tembus karena ketajamannya, namun berkat kelebihan yang

\footnotetext{
${ }^{5}$ Martin Van Bruinessen, Kitab Kuning..., hlm.277.
}

${ }^{6} \mathrm{Al}$ Madad berasal dari bahasa Arab (Madadun) yang berarti pertolongan. Lihat Mahmud Yunus, Kamus Arab Indonesia, (Jakarta : Hidayakarya Agung, 1989 ), hlm. 414.

${ }^{7}$ Departemen Pendidikan dan Kebudayaan, Sejarah Daerah Jawa Barat, (Jakarta : Balai Pustaka, 1997 ), hlm. 115. 
dimiliki oleh seorang pemain debus, alat tersebut tidak dapat menembus tubuhnya, bahkan tidak luka sedikitpun. ${ }^{8}$

Sejak kemunculannya, debus merupakan sebuah media dakwah untuk mengislamkan masyarakat Banten yang masih menganut ajaran agama Hindu dan Budha. Proses ini dimulai pada zaman Sultan Hasanuddīn, yang pada saat itu pemegang tampuk kekuasaan pada Kesultanan Banten pada tahun 1570 M. ${ }^{9}$

Dilihat dari sejarahnya, kesenian tradisional debus Banten bersumber dari ajaran beberapa tarekat. Hal ini terlihat dari latar belakang Sultan Hasanuddin sendiri yakni sebagai orang yang pertama yang memperkenalkan kesenian tersebut dan juga termasuk penganut ajaran beberapa tarekat. Tarekat-tarekat yang diperkirakan mempengaruhi secara kuat terhadap kesenian debus tersebut adalah tarekat Qādirīyah, Rifá'iyah, Syādziliyah, dan Naqsyabandiyah, hal ini dapat dilihat dari silsilah, ritual, hizib dan bacaan-bacaan wirid atau zikir yang dibacakan pada setiap pertunjukan dan tata cara mempelajari kesenian debus Banten.

Melihat latar belakang penciptaan debus yang berasal dari ajaran tarekat tentunya sangat berhubungan dengan dunia tasawuf yang kemudian mengalami perkembangan sehingga menjadi sebuah ikatan yang kuat dan erat, seperti yang diungkapkan oleh Harun Nasution sebagai berikut :

Sufi-sufi mempunyai pengikut atau ikatan, akan tetapi pada abad kedua belas masehi bermunculan organisasi-organisasi yang bernama tarekat, yaitu jalan yang harus ditempuh oleh calon seorang sufi dalam tujuannya berada sedekat mungkin dengan Tuhan, kalimat tarekat kemudian berkembang menjadi organisasi, dimana ritual dan bentuk zikir tersendiri..$^{10}$

Tasawuf dalam Islam adalah ajaran yang mencontohkan sikap dan sifat Rasulullah saw, yang dikenal berakhlak luhur, zahid, qanaah, wara, banyak berzikir, dan selalu mensucikan jiwanya dari

${ }^{8}$ Sandjin Aminudin, dalam Sri Sutjianingsih (peny.), Banten Kota Pelabuhan Jalan Sutra, (Jakarta : Dirjen. Kebudayaan dan Sejarah Nilai-nilai Tradisional, 1995),, hlm.157.

${ }^{9} \mathrm{~Tb}$ Ismet Al Abbas, Sejarah dan Objek Spiritual Banten, (Banten : Dinas Pendidikan, 1990), hlm. 9.

${ }^{10}$ Harun Nasution, Islam Ditinjau Dari Berbagai Aspeknya, (Jakarta : UI Press, 1966), hlm. 89. 
segala hawa nafsu yang menyesatkan serta membersihkan diri dari segala penyakit hati, sebagaimana firman Allah swt dalam QS. AlAhzab : 21 .

Di sisi lain, keeratan debus dengan dunia tarekat bisa dilihat juga pada setiap akan dimulainya pertunjukan debus yang selalu dimulai dengan membaca shalawat-shalawat Nabi, do'a-do'a dan zikir yang memohon perlindungan dari Allah swt serta diikuti dengan ritual tertentu, yang ternyata ritual tersebut sama juga dilakukan oleh beberapa tarekat.

Diajarkannya beberapa bacaan do'a (atau biasa disebut dengan wiridan) yang berasal dari tarekat adalah sebagai alat untuk mempermudah si murid dalam meraih hidayah dari Allah swt. Dengan diraihnya hidayah oleh si murid, maka ia akan cepat sampai pada tingkatan manusia yang bertaqwa, dan apabila si murid sudah menjadi orang yang bertaqwa maka akan mudahlah diraih suatu keajaiban-keajaiban atau pekerjaan-pekerjaan luar biasa yang dalam istilah tasawuf hal demikian disebut dengan "karomah". ${ }^{11}$

Debus di awal kemunculannya tidak bisa dipraktekkan oleh sembarang orang. Sebab yang dapat melakukan praktek debus hanya orang yang sudah taat betul dengan ajaran-ajaran agama. Apabila orang yang belum taat dalam mengamalkan ajaran agama melakukan hal semacam debus tersebut, maka senjata tajam yang digunakan tersebut bisa melukai tubuh orang tersebut.

Dilihat dari perkembangannya, kesenian tradisional debus yang pada mulanya berasal dari tarekat, pada fase selanjutnya kemudian ter-akulturasi oleh tradisi lokal. Hal ini disebabkan karena Banten dikenal sebagai daerah yang kental dengan tradisi lokal yang berbau magis. Cerita-cerita seputar tempat-tempat yang dianggap keramat dan sampai kini sering dikunjungi oleh masyarakat seperti yang direkam oleh Hosein Djajadiningrat adalah daerah pengunungan seperti; Gunung Pulosari, Gunung Karang dan lainnya. ${ }^{12}$

Aspek magis seperti kekebalan dan kesaktian sejak pra-Islam

${ }^{11}$ Abubakar Aceh, Pengantar Sejarah Sufi dan Tasawuf, (Solo : Ramadhani,1989), hlm. 354.

${ }^{12}$ Hosein Djajadiningrat, Tinjauan Kritis tentang Sejarah Banten, (Jakarta: Djambatan, 1983), hlm. 34. 
memang dipentingkan dan dicari banyak orang. Dalam lagendalagenda tentang para wali misalnya, kemenangan Islam sering dihubungkan dengan keunggulan zikir dan wirid para wali Islam dibandingkan dengan mantra dan jampi-jampi kepercayaan lokal dalam agama Hindu-Budha. Karena itu, banyak orang yang berasumsi bahwa pesatnya Islam pada masa-masa awal di Nusantara karena disebabkan Islam sudah "dibungkus" tradisi tarekat dalam tasawuf yang dekat dengan budaya Nusantara. Karena alasan inilah, maka kemudian banyak di antara masyarakat yang kemudian mencari dan mengharapkan bahwa dengan masuk tarekat, mereka akan mendapatkan elmu yang kuat. ${ }^{13}$

Hal ini memang wajar terjadi, karena di antara tarekat yang ada, kerapkali kental dengan nuansa magis seperti dalam tarekat Qādirìyah dengan Syaikhnya 'Abd al-Qādir Jilāni. Dalam masyarakat Indonesia, tokoh ini dikenal sebagai wali yang terbesar. Lagenda tentang riwayat hidupnya yang berbau magis kerapkali dilantunkan yang disebut dengan "manaqib Syaikh 'Abd al-Qādir Jilānī” oleh masyarakat Indonesia sampai saat ini. Mereka mempercayai bahwa dengan pembacaan manaqib itu, maka si pembaca akan mendapatkan sisi barakah dari sang Syaikh sendiri seperti yang dipercayai oleh para pelaku debus Banten sampai saat ini.

\section{Pergeseran Otentisitas Dalam Debus Banten}

Kehadiran kesenian debus Banten dalam sejarahnya mempunyai peranan yang sangat luar biasa. Debus yang pada awalnya adalah alat atau media yang digunakan sang sultan (raja) untuk mencoba menandingi kesaktian yang dimiliki oleh para elite kerajaan Sunda atau Padjajaran pada waktu itu. ${ }^{14}$ Di samping itu, kesenian debus juga dalam sejarahnya dijadikan sebagai media

\footnotetext{
${ }^{13}$ Martin Van Bruinessen, Kitab Kuning, Pesantren dan Tarekat........., hlm. 221.

${ }^{14}$ Seperti yang diceritakan dalam Babad Banten bahwa saat itu yakni Sultan Hasanuddin ketika melakukan peperangan dengan Prabu Pucuk Umun di Banten Girang dilakukannya dengan metode beradu kesaktian dan sabung ayam. Menurut ceritanya, ayam yang dimiliki oleh Sultan Hasanuddin mempunyai "kesaktian" luar biasa sehingga bisa mengalahkan ayam yang dimiliki oleh Prabu Pucuk Umun. Hoessein Djajadiningrat, Tinjauan Kritis tentang Sejarah Banten, (Jakarta: Djambatan, 1981), hlm. 34-35.
} 
dakwah atau syi'ar Islam seperti diceritakan oleh salah seorang tokoh debus. Ia menceritakan bahwa pada zaman kesultanan Banten dahulu, debus hanya diatraksikan di masjid-masjid atau alunalun kerajaan. Jika masyarakat hendak menonton pertunjukan itu, maka mereka dianjurkan membayar karcis dengan mengucapkan dua kalimat syahadat. ${ }^{15}$ Hal ini membuktikan bahwa debus tempo dulu murni bertujuan syi'ar keagamaan.

Kesenian debus pada awalnya adalah murni berasal dari tarekat. Permainan debus dalam tradisi tarekat berfungsi untuk mengetahui tingkat kefanaan seorang murid ketika ia melakukan wirid dan zikir. Hal ini dibenarkan jika melihat pada pernyataan Hamka yang mengatakan bahwa ketika seorang murid telah mencapai tahap fana, maka akan ditandai dengan kemampuan untuk melakukan hal yang luar biasa yang keluar dari hukum alam. ${ }^{16}$

Kejadian-kejadian luar biasa itu dalam tarekat dipandang sebagai suatu tanda "kehormatan" dari Allah terhadap hambanya yang telah mensucikan jiwanya dan terus berusaha untuk mendekati-Nya. Keajaiban yang luar biasa itu sering diceritakan dan dimiliki oleh seorang guru sufi. Dan di antara guru sufi yang dikenal dengan hal seperti itu adalah Syaikh 'Abd al-Qādir Jilānī, Syaikh Ahmad Ibn 'Ali ar-Rifā'i.

Akan tetapi, seiring dengan perkembangan zaman, kesenian debus saat ini sudah mengalami akulturasi dengan tradisi lokal lainnya yang ada di Banten dan unsur-unsur lokal dari Pra-Islam. Sehingga dengan proses akulturasi tersebut, maka terkadang sulit untuk membedakan secara tegas antara ritual tarekat di satu sisi dan ritual debus hasil adopsi tradisi lokal di sisi lain.

Dengan mengalami akulturasi, kesenian debus dengan tradisi lokal bahkan teknologi modern, maka secara tanpa disengaja, kesenian ini pun mengalami penyusutan kemurniannya, atau dengan kata lain, debus sudah mengalami pergeseran. Dari hasil pengamatan di lapangan, pergeseran itu meliputi;

${ }^{15}$ Wawancara dengan Kyai Mudzakir, Tokoh Ulama, 18 Februari 2007. dan Wawancara dengan Attak, Sejarahwan dan Penggali Situs Arkeologi Banten, 19 Februari 2013.

${ }^{16}$ Hamka, Tasawuf: Perkembangan dan Pemurniannya, (Jakarta: Yayasan Nurul Islam, 1980), hlm. 157. 


\section{a. Pergeseran Dari Segi Ritual}

Dari hasil pengamatan di lapangan dan penelusuran data sejarah debus, dan mencoba menggunakan cara perbandingan antara tradisi ritual yang dipraktekkan antara debus tempo dulu dan debus sekarang, nampaknya sudah mengalami pergeseran yang begitu jauh, meskipun dalam kesenian debus sekarang juga masih dipraktekkan beberapa ritual tradisi yang dikenal dalam Islam khususnya tasawuf. ${ }^{17}$

Di antara pergeseran dari segi ritual yang dipraktekkan dalam kesenian debus yang berasal dari akulturasi tradisi Islam dan tradisi budaya lokal adalah sebagai berikut:

1. Pembacaan Wirid

Wirid merupakan bacaan-bacaan do'a pendek yang isinya adalah pujian akan keagungan Tuhan. Dalam tarekat dan debus -baik dulu maupun sekarang- pembacaan wirid mempunyai peranan yang sangat penting dan harus dijaga karena semua itu bertumpu pada pembacaan wirid ini. jika sang murid mempraktekkan ritual ini dengan tekun, maka akan melahirkan kekuatan lain yang luar biasa yang ada dalam atraksi debus seperti kebal senjata tajam dan lainnya.

Meskipun pembacaan wirid dalam tarekat dan debus mempunyai peranan penting. Akan tetapi, antara keduanya berbeda dari segi orientasinya. Dalam tarekat, pembacaan wirid pada awalnya dilakukan hanya semata-mata dalam rangka mencapai kedekatan dengan Tuhan, yang apabila sudah merasa dekat dengan Tuhan, dalam kondisi fana, maka sebagai buktinya akan bisa melakukan hal-hal yang diluar hukum alam. Orientasi itu berbeda dalam debus. Dalam debus, ketika sang murid mendapatkan ijazah atau restu untuk mengamalkan wirid itu, maka orientasi yang ada dibenaknya ketika membaca wirid

${ }^{17}$ Dalam proses pengamatan ini, penulis tidak hanya mendengar dan mencatat saja, akan tetapi diiringi dengan terjun langsung ke lokasi padepokan debus dalam hal ini yang ada di daerah Walantaka. Sesekali penulis mencoba mempraktekkan berbagai cara ritual dan atraksi yang dimainkan dalam debus Banten. Cara ini penulis lakukan untuk merasakan apakah betul mereka melakukan atraksi berbahaya itu dalam kondisi sadar atau tidak. Dan teryata penulis merasakannya dalam kondisi sadar. 
tersebut adalah keinginan untuk mencapai hal-hal yang luar biasa, seperti kesaktian. Atau dalam istilah sederhana, wirid yang dilakukan dalam debus hanya semata-mata "ngelmu". Argumentasinya bahwa, jika seseorang berkeinginan mempunyai keahlian debus, maka ia tidak diwajibkan baik itu mengikuti atau mengenal tradisi dan ritual tarekat. Sehingga dengan seperti ini, wajar jika para guru debus dan para muridnya saat ini tidak mengenal bahwa debus yang mereka pelajari sebenarnya berasal dari tarekat.

\section{Tawasul (pembacaan silsilah)}

Pembacaan silsilah adalah merupakan ciri khas yang dipraktekkan-baik itu dalam tarekat maupun debus. Antara tarekat dan debus memandang pembacaan silsilah menjadi sesuatu yang sangat diperlukan demi tercapainya kemajuan spiritual. Bagi keduanya, untuk sampai kepada Tuhan, seseorang harus mendapatkan bimbingan dan campur tangan aktif dari pihak pembimbing spiritualnya dan para pendahulu sang pembimbing, termasuk di dalamnya paling penting adalah Nabi Muhammad saw.

Pembacaan silsilah ini-baik itu dalam tarekat maupun debus-ditujukan untuk menunjukan transmisi keilmuan, juga merupakan upaya untuk meminta pertolongan kepada para Syaikh terdahulu untuk disampaikan maksudnya kepada Allah swt. Yang menarik dari silsilah dalam kesenian debus saat ini adalah bercabangnya orientasi tujuan. Meskipun pembacaan rangkaian silsilah terhadap gurunya tetap dilakukan, akan tetapi mereka kerap kali melakukan silsilah lain yang disebut dengan sambatan, yakni meminta bantuan dari makhluk yang lain, seperti Jin atau lainnya, sehingga dengan cara seperti ini, mereka mampu melakukan perbuatan-perbuatan seperti macan, monyet atau makhluk lainya. Selain itu dikenal juga hadiran, yakni menghadirkan sosok tertentu untuk membantu dalam melakukan sesuatu sesuai dengan kehendak sang pelaku. Ritual-ritual atau cara seperti ini nampaknya sudah mengalami penyimpangan dari tradisi pembacaan silsilah dalam tarekat-tarekat.

3. Jangjawokan

Dalam tarekat dan juga dalam tradisi debus awal, istilah 
jangjawokan memang tidak dikenal. Istilah ini muncul ketika debus sudah mengalami akulturasi dengan budaya lokal. Jangjawokan adalah bacaan-bacaan lokal yang diyakini mempunyai kekuatan luar biasa yang apabila diamalkan atau dirutinkan dengan penuh kesungguhan dan diikuti segala ketentuanya, si pelaku akan mempunyai kemampuan yang luar biasa. Berbeda dengan wirid dalam tarekat yang berbahasa Arab, Jangjawokan mempergunakan bahasa Jawa atau Sunda, yang maknanya juga terkadang sudah tidak dapat dipahami sekalipun oleh orang yang mengamalkan.

Dalam sejarahnya, Jangjawokan merupakan sisa-sisa dari kepercayaan pra-Islam di Banten. Masyarakat Banten sebelum Islam masuk dan dianut oleh mereka, mereka telah memiliki kecenderungan yang kuat pada hal-hal yang berbau kekuatan mistis. Oleh karena itu, maka tidak aneh jikalau masih dapat dijumpai tentang sisa-sisa kepercayaan seperti ini.

Meskipun begitu, pada masa perkembangannya, istilah Jangjawokan tidak hanya murni kepercayaan yang dianut oleh masyarakat pra-Islam. Istilah dan amalah wirid Jangjawokan juga ternyata sudah mengalami akulturasi dengan budaya Islam. Sehingga dengan demikian tak aneh jika saat ini banyak sekali bacaan Jangjawokan yang sudah bercampur dengan bacaan yang terdapat dalam Islam. Seperti kerapkali bacaan Jangjawokan selalu dimulai dari bacaan basmallah, syahadat, dan kalimat lā illāha illa Allāh.

4. Permainan Silat

Permaianan silat dalam pertunjukan debus sekarang ini adalah sesuatu yang baru. Sebelumnya debus tidak diiringi dengan permainan silat, namun hanya diikuti oleh tarian saja. Permainan silat dalam pementasan debus akhir-akhir ini merupakan upaya penggabungan seni atau tradisi dengan permaian debus yang asli.

Sejarah ilmu persilatan di Banten memiliki akar yang sangat panjang. Di masa pra-Islam dikenal istilah "paguron" atau "padepokan” di daerah sekitar Gunung Karang, Pandeglang ${ }^{18}$.

${ }^{18}$ Martin Van Bruinessen, Kitab Kuning Pesantren dan Tarekat, (Bandung : Mizan, 1995), hlm. 25. 
Pada masa lalu tradisi persilatan nampaknya menjadi suatu kebutuhan individu-individu tertentu untuk mempertahankan diri dan kelompoknya. Hidup di daerah-daerah terpencil dan sangat rawan dari tindakan-tindakan kriminal dari pihak lain, hal ini tentunya membutuhkan keberanian untuk memiliki kekuatan fisik yang baik. Hal inilah yang nampaknya mendorong setiap individu berusaha utuk membekali dirinya dengan kemampuan bela diri dengan belajar silat.

Akan tetapi sekarang ini muncul kecenderungan kuat bahwa permainan debus itu bukan untuk mereka yang ingin belajar tarekat, tetapi mereka yang semenjak awal sudah tertarik pada ilmu persilatan, terutama pada klompok para jawara. Para jawara tersebut mendapatkan "elmu" kedigdayaan tanpa pernah adanya suatu selektif untuk memilah antara yang berasal dari tradisi tarekat atau tradisi lokal. Yang paling penting bagi jawara adalah memiliki ilmu-ilmu kanuragan atau kesaktian yang dipergunakan sesuai kebutuhan.

5. Musik Pengiring

Musik yang mengiringi permainan debus adalah musik tradisional masyarakat Banten, bukan musik yang berasal dari tradisi masyarakat Arab atau Timur Tengah. Alat-alat musik yang dipergunakan dalam permainan debus biasanya terdiri dari 5 macam yaitu: (1) satu buah gendang ukuran sedang, (2) dua buah kulantir (gendang kecil), (3) satu buah terbang gede (terbang besar), (4) dua buah dog-dog kecil, (5) satu atau dua buah kecrek.

Pada zaman debus tempo dulu, sebenarnya tidak ada iringan musik, yang ada adalah iringan pembacaan shalawat Nabi ketika pertunjukan debus di mulai. Bahkan tidak hanya itu, pergeseran debus juga terjadi dari segi peralatan yang digunakan. Debus tempo dulu hanya menggunakan terbang sebagai iringan pertunjukan debus.

Dengan demikian, alat-alat yang digunakan dalam kesenian debus saat ini adalah sesuatu hal yang baru. Dan perpaduan itu terjadi dengan kesenian-kesenian lainnya yang ada di Banten. Seperti alat musik gendang adalah alat musik khas kesenian silat yang kemudian dipakai juga oleh debus saat ini. 


\section{Atraksi Debus}

Kalau kita melihat seputar atraksi yang dimainkan dalam kesenian debus akhir-akhir ini, banyak sekali permainan yang sebenarnya tidak pernah dilakukan pada masa debus tempo dulu atau debus awal. Banyak sekali pertunjukan debus saat ini sudah bercampur dengan berbagai trik atau sulap pertunjukan. Seperti atraksi mengupas kelapa dengan mulut, kelelawar yang keluar dari mulut, atau kelapa berisi mie dan banyak lagi yang lainnya. Semua itu dilakukan demi untuk menambah nilai hiburan semata.

Adanya penambahan praktek pertunjukan debus ini, jika kita mengacu pada teori tentang adanya faktor terjadinya perubahan kebudayaan dalam masyarakat yakni salah satunya teori pembaruan atau inovasi, maka apa yang dilakukan oleh para pemain debus yang ada di Banten, bisa dikategorikan sebagai langkah pembaruan atau inovasi. Langkah pembaruan dalam debus ini memang di satu sisi menguntungkan karena akan menambah pengayaan atraksi dan penambahan penghasilan, akan tetapi di sisi lain, justru merugikan bahkan secara tidak langsung menghancurkan debus itu sendiri dari dalam, karena akan mengotori nilai kemurnian dari tradisi debus itu sendiri yang seharusnya dijaga.

Lebih menarik lagi, dalam kesenian debus saat ini ada yang dinamakan dengan istilah "debus tempel" yakni suatu penempelan atau transfer kesaktian secara instan kepada seseorang, baik itu orang dewasa atau anak-anak, baik itu laki-laki atau perempuan dan "kesaktian tempel" ini hanya bersifat temporal. Kesaktian tempel sebenarnya sudah menyimpang dari tradisi tarekat. Karena dalam tarekat, proses mendapatkan kekuatan yang luar biasa hanya dapat dicapai oleh para pelaku tarekat yang sudah mencapai tahap fana'.

\section{b. Pergeseran Dari Segi Pertunjukan}

Penelusuran pergeseran dari segi pertunjukan debus saat ini adalah hal lain yang menarik untuk diamati. Kalau kita bandingkan dengan sejarah debus tempo dulu dan praktek debus yang kebal 
akan senjata tajam dalam tradisi tarekat maka proses pelaksanaan ritual dilakukan dalam waktu yang bersamaan. Dalam tradisi tarekat misalnya, pembacaan silsilah dilakukan sebelum acara zikir tarekat di mulai. Prosesi di atas berbeda dengan praktek debus saat ini. Meskipun dari hasil wawancara dengan beberapa guru debus yang mengatakan bahwa silsilah dalam debus adalah sesuatu yang penting bahkan dianggap sakral, ${ }^{19}$ akan tetapi kenyataanya di lapangan, pertunjukan debus kerapkali tidak membacakan silsilah sebagai pendahuluan pertunjukan. Fenomena ini jika kita bandingkan dengan ritual yang ada dalam tarekat sangatlah berbeda bahkan bertolak belakang.

Tidak hanya itu, dari pengamatan di lapangan, ditemukan bahwa dalam setiap pertunjukan debus, pembacaan manaqib Syaikh 'Abd al-Qādir Jilānỉ kerapkali dilupakan atau tidak dibaca. Padahal kalau kita bandingkan dengan praktek ritual yang dipraktekkan dalam pertunjukan debus tempo dulu, pembacaan manaqib selalu dibaca sebelum pertunjukan debus dimulai. Ditinggalkannya prosesi pembacaan manaqib sebelum pertunjukan disebabkan adanya kekhawatiran akan adanya perasaan kecewa bagi penonton yang menyaksikan pertunjukan debus. Sehingga untuk mengantisipasi akan terjadinya hal itu, para pemain melakukan ritual tidak pada saat pertunjukan akan dimulai melainkan dilakukan sehari sebelum pertunjukan. ${ }^{20}$ Dari penemuan di atas, semakin jelas bahwa praktek debus saat ini sudah mengalami perubahan dari debus tempo dulu. Dari fenomena di atas dapat ditarik kesimpulan bahwa pada saat ini, permainan debus lebih pada mementingkan aspek pertunjukan yang inti saja, dan melupakan prosesi ritual yang padahal menurut mereka sendiri dianggap sesuatu yang sakral.

\section{c. Pergeseran Dari Segi Perekrutan Personil Debus}

Sisi menarik lainnya yang patut mendapatkan perhatian lebih adalah pada pola perekrutan para pemain debus. Jika kita melakukan pembacaan ulang terhadap sejarah kemunculan debus, maka dari data yang ditemukan bahwa debus berasal dari tarekat.

${ }^{19}$ Wawancara dengan wayut, Salah seorang guru debus Surosowan, 20 Februari 2013

${ }^{20}$ Wawancara dengan Jaya, salah seorang murid debus, 20 Februari 2013 
Keahlian untuk bisa bermain debus tidaklah dilakukan dengan mudah. Pencapaian untuk bisa bermain debus haruslah melakukan zikir yang ada dalam tarekat sampai pada keadaan kondisi yang fana'. Ketika seorang murid tarekat melakukan zikir sampai pada fase fana', maka ia akan bisa melakukan atraksi yang kebal akan senjata tajam. Akan tetapi berbeda dengan debus saat ini, untuk bisa bermain debus, kita tidak lagi diharuskan untuk memasuki tarekat tertentu. Praktek debus bisa dilakukan tanpa masuk tarekat. Dengan demikian, para pemain debus, atau bahkan guru debus sendiri terkadang bukan seorang penganut tarekat.

Tidak hanya itu, dilihat dari para pemain debus, ada di antaranya yang masih anak-anak, bahkan lebih dari itu, penggunaan anak-anak di bawah umur dalam setiap atraksi debus saat ini akan lebih mendapatkan keuntungan materi. Padahal kalau kita bandingkan dengan tradisi yang ada dalam tarekat, anak-anak di bawah umur tidak dibolehkan untuk mengikuti ritual tarekat karena dianggap belum cukup umur. Akan tetapi, jika kita lihat pertunjukan debus saat ini, penggunaan anak-anak di bawah umur untuk mempraktekkan keahlian ber-debus adalah sesuatu yang menarik dan diminati sebagai pendongkrak penghasilan bagai para pemain debus. Dari fenomena ini dapat disimpulkan bahwa debus saat ini benar-benar sudah terputus dengan tarekat. Lalu pertanyaannya mengapa hal itu terjadi ?, lagi-lagi alasannya agar atraksi debus dapat diterima masyarakat dan sesuai dengan perkembangan zaman.

\section{d. Pergeseran Dari Segi Tujuan}

Dalam kesenian debus saat ini tidak hanya terjadi pada pergeseran dari segi ritual, pertunjukan atau perekrutan saja, pergeseran itu juga terjadi pada segi tujuan permainan debus. Pergeseran ini adalah sebuah kelanjutan dari adanya pergeseranpergeseran debus di atas. Kesenian debus saat ini sudah mengalami pergeseran dari segi tujuannya dengan debus tempo dulu. Sekarang, meskipun padepokan debus tumbuh menjamur di mana-manabaik itu di sekitar Banten sendiri maupun luar Banten-akan tetapi semuanya lebih menekankan pada orientasi hiburan daripada tarekat murni.

Hubungan antara tarekat dan debus saat ini sudah renggang 
bahkan bisa dikatakan cerai atau terputus karena debus sudah beralih orientasi menjadi hiburan yang mendatangkan uang dan aset pariwisata yang layak jual. Bahkan sungguh ironi, ketika penelitian lapangan ini dilakukan, banyak di antara para guru debus atau para pemain debus yang tidak mengetahui atau paham kalau sebenarnya kesenian yang mereka pelajari selama ini berasal dari tarekat. ${ }^{21}$

Jika kita pakai teori ekonomi yang dikemukakan oleh Karl Marx yang menyatakan bahwa kekuatan-kekuatan material merupakan hal-hal yang menetukan bagi perubahan dalam masyarakat dan perkembangan evolusi manusia, bahwa perekonomian merupakan pondasi untuk membentuk masyarakat karena merupakan kebutuhan mahluk hidup, maka kesenian debus saat ini memang begitu adanya. Debus bukan lagi sebagai media dakwah Islam, akan tetapi sudah beralih fungsi menjadi media bisnis hiburan yang mendapatkan penghasilan, jika tidak dikatakan sebagai lahan pekerjaan yang menguntungkan. Bahkan lebih dari itu, debus kini sudah menjadi aset wisata daerah Banten yang bisa "dijual" ke berbagai daerah bahkan sampai ke luar negeri untuk menarik wisatawan berkunjung ke Banten.

\section{Negosiasi Islam dan Budaya Lokal dalam Debus}

Pada bagian ini akan di jelaskan lebih lanjut tentang keberadaan debus dalam konteks budaya Islam yang lebih luas pada masyarakat Banten bahkan untuk Islam di Nusantara. Debus merupakan salah satu contoh dari akulturasi antara budaya Islam dengan budaya lokal. Islam yang pertama kali berkembang di daerah Timur Tengah, tepatnya di Negeri Arab Saudi sekarang, mengalami adaptasi dengan budaya masyarakat setempat ketika ia di peluk oleh para penduduk Nusantara. Sehinggga sering terjadi adanya sinkretisme dalam beragama. Adaptasi Islam dengan budaya lokal tersebut sebagai sesuatu yang tak terhindarkan agar Islam diterima mayoritas penduduk lokal, namun adaptasi tersebut sering menimbulkan ketegangan-ketegangan antara keharusan untuk mempertahankan ontentisitas Islam dengan kebutuhan-kebutuhan

${ }^{21}$ Di antara guru debus yang penulis wawancarai seputar pertanyaan asal-usul debus berasal dari tarekat adalah; Wayur, Kyai Mudzakir, dan Mamad. 17 Februari 2013 
praktis dan populer yang telah dianut secara luas oleh masyarakat lokal di Indonesia

Tanpa menghilangkan beberapa pengecualian tantang proses penyebaran Islam di Indonesia, namun secara umum proses Islamisasi di Indonsia berlangsung secara damai. Karena itu, masyarakat Indonesia merupakan satu dari sedikit wilayah di Dunia yang mengalami proses Islamisasi penduduknya tanpa kekuatan militer. Islam menyebar ke sejumlah wilayah di Nusantara melalui jalur perdagangan dan jaringan tarekat yang sangat akomodatif terhadap budaya-budaya lokal. Para penyebar sufi-pedagang mempergunakan simbol-simbol budaya dan pranata sosial lokal yang telah ada untuk menghadirkan Islam di tengah kehidupan masyarakat Nusantara.

Sarana dan simbol budaya lokal yang terpakai oleh para penyiar Islam di Jawa seperti pertunjukan wayang, penggunaan "elmu" kesaktian yang telah lama dikenal sejak lama oleh masyarakat Nusantara dan tradisi-tradisi yang telah lama diterima masyarakat secara luas seperti pernikahan, kematian, kelahiran serta acaraacara yang telah dianggap penting dan mapan lainnya. Dalam kasus Banten, Sultan Hasanuddin, sebelum ia menjadi penguasa di daerah ini, ia mempelajari budaya yang berkembang pada masayarakat Banten pra-Islam dan menghormatinya sebagai bagian dari budaya masyarakat sekitar. Karena itu, ia pun memandang untuk melakukan tapa di tempat-tempat yang dikenal sebagai keramat. Bahkan untuk menaklukan Pucuk Umun (pewaris tahta kerajaan Sunda), ia mempergunakan budaya lokal yang berkembang saat itu, yakni mengadakan sabung ayam.

Meskipun cerita-cerita yang berkembang di tengah masyarakat Banten tentang Sultan Hasanuddin itu lebih bersifat mitos, karena kebenaran sejarahnya masih diragukan, namun itu menggambarkan bahwa para penyiar agama Islam terdahulu mempergunakan simbol, tradisi, institusi dan budaya lokal yang telah lama berkembang di masyarakat untuk memperkenalkan Islam pada masyarakat Nusantara. Oleh karena itu, masyarakat di Nusantara meskipun telah memeluk Islam sebagai agama mereka, namun tidak banyak mengalami perubahan yang sangat besar dalam budaya dan intitusi sosial mereka. Masyarakat di Nusantara tetap berpakaian dan berbahasa sedia kala, tidak diganti dengan pakaian 
dan Bahasa Arab, seperti terjadi di Mesir, Irak dan Negeri lainnya di Timur Tengah dan Afrika.

Tidak terkecuali dalam hal ini debus. Debus yang merupakan tradisi yang dikenal dalam tarekat, khususnya tarekat Qādiryah, sebagai pertanda bagi murid yang telah mencapai derajat (maqām) tertentu, menjadi sarana yang efektif dalam memperkenalkan Islam di Banten dan daerah lainnya di Nusantara yang memang dikenal sangat kental akan kepercayaan kepada kekuatan mistis.

Meskipun dalam tahapan perkembangan selanjutnya, debus mengalami perkembangan yang complicated ketika menjadi kepercayaan populer di masyarakat awam. Permainan debus pada akhirnya tidak hanya merujuk pada sumber tarekat yang ada, tetapi dari tradisi lokal yang telah lama populer di masyarakat. Sehingga permainan debus yang sekarang ini kita dapatkan seolah telah tercabut dari akar yang sebenarnya, yakni bagian dari tradisi tarekat. Kini permainan debus lebih dikenal sebagai pertunjukan permainan orang-orang yang memiliki "elmu" kesaktian.

Hasil Islamisasi dengan cara demikian itu memang sangat efektif untuk menarik penduduk Nusantara memeluk Islam secara luas, sehingga kini Indonesia dikenal sebagai salah satu bangsa Muslim terbesar di Dunia. Namun demikian, Islamisasi dengan model tersebut juga menghasilkan praktek sinkretisme yang luas dalam keberagamaan masyarakat Indonesia.

Debus merupakan bagian dari kebuadayaan masyarakat Bantenyangbersifatsinkretis, karenabanyakmengambildariberbagai sumber, yakni Islam, Hindu, Budha, dan Animisme. Kebanyakan para pemain debus sekarang ini, tidak seutuhnya mengambil dari tradisi tarekat tetapi juga mentransfer unsur-unsur yang berasal dari tradisi pra-Islam. Bacaan-bacaan sakti, seperti jangjawokan, dan permainan-permainan di dalamnya tidak lagi mengikuti lagi tradisi tarekat yang memperkenalkannya tetapi diambil dari peraminanpermainan silat dan ilmu kanuragan yang berasal dari tardisi praIslam. Berdasarkan cara pandang di atas bahwa debus merupakan produk dari kebudayaan masyarakat Banten yang bersifat sinkretis, di mana-mana unsur lokalnya itu lebih dominan, sedangkan Islam itu hanya ada pada kulit luarnya saja yakni sebagai pembungkus semata, agar bisa diterima masyarakat yang lebih luas. 
Permainan debus kini bisa dikatakan merupakan tiruan dalam bentuk populer dari tradisi tarekat. Para pemimpin tarekat, yakni para sufi, memang dikenal sebagai orang-orang khawash yang telah dipandang mencapai derajat intelektual dan ketakwaan yang tinggi. Sebagai orang yang telah mencapai derajat yang begitu tinggi di samping Allah, mereka dianugrahi beberapa kelebihan dari manusia kebanyakan, yang dikenal dengan "karamah". Berkat "karamah" yang dimilikinya tersebut seorang sufi bisa melakukan hal-hal yang keluar dari hukum alam.

Para pemain debus kini mayoritas dikenal sebagai jawara, pendekar atau pemain silat, berusaha untuk meniru apa yang dilakukan oleh para ahli sufi atau guru tarekat. Karena itu debus merupakan bentuk tiruan populer dari tradisi tarekat yang lebih rumit dari debus yang aslinya. Ia tidak hanya mengadopsi tarekat sebagai sumber mendapatkan kesaktian tetapi juga dari tradisi masyarakat Banten pra-Islam sendiri yang juga selama ini dikenal memiliki kekayaan budaya tentang hal-hal yang berkaitan dengan kekuatan mistis.

Tidak dapat diingkari, bahwa tradisi ngelmu dalam masyarakat Banten telah berkembang jauh sebelum Islam masuk ke daerah ini dan telah menjadi kepercayaan yang mengakar kuat pada masyarakat umum. Ketika Islam berhasil memasuki daerah ini, Islam berusaha mengubah orientasi kebudayaan yang telah ada di masyarakat sesuai dengan tujuan ajaran Islam. Perubahan tersebut biasanya tidak menghancurkan simbol atau wadah yang ada, tetapi yang dirubah esensi atau isi dari kebudayaan itu yang disesuaikan dengan ajaran Islam

Permainan debus, semenjak awal, merupakan tradisi yang telah berkembang di dunia tarekat. Ketika masuk dan berkembang di Banten dan di daerah-daerah lain di Nusantara. Maka ia beradaptasi dengan budaya lokal yang terlebih dahulu berkembang. Namun jelas proses adaptasi tersebut merupakan "penjinakan" budaya lokal tersebut agar lebih sesuai dengan ajaran-ajaran Islam sehingga Islam akan lebih mudah diterima oleh masyarakat.

\section{E. Kesimpulan}

Kesenian debus adalah salah satu kesenian lokal masyarakat 
Banten. Kesenian yang satu ini berbeda dengan kesenian pada umumnya. Dalam pertunjukannya ia lebih memperlihatkan aspek kekuatan fisik atau kekebalan atas senjata tajam.

Akan tetapi tak sedikit di antara masyarakat yang menganggap bahwa kesenian ini adalah sebuah kesenian yang menyimpang dan termasuk bid'ah bahkan lebih ekstrim lagi tak sedikit di antara masyarakat yang menganggap bahwa kesenian ini dapat menyimpangkan para peminatnya pada hal-hal syirik. Penilaian itu menurut saya adalah penilaian yang terburu-buru dan tak melihat akar sejarah tradisi kesenian debus itu sendiri. Padahal kalau kita telusuri awal sejarah kesenian debus ini muncul adalah berasal dari tarekat yang ada dalam tradisi tasawuf.

Sesuai dengan tema permasalahan yang diangkat dalam penelitian ini, maka dapat diambil beberapa kesimpulan sebagai jawaban; Kehadiran kesenian debus dari mulai sejarah munculnya dan alasan kemunculan kesenian ini sudah mengalami pergeseran jauh bahkan bertolak belakang dengan kesenian debus yang dipraktekkan saat ini. Pergeseran itu pertama, terjadi pada segi ritual debus. Kalau kita amati debus saat ini ada beberapa ritual yang sebenarnya tidak pernah dilakukan oleh debus tempo dulu di antaranya adalah Jangjawokan adalah bacaan-bacaan yang diyakini mempunyai kekuatan luar biasa apabila diamalkan dengan penuh kesungguhan dan diikuti segala ketentuanya. Terjadinya proses pergeseran ritual debus itu karena debus sudah mengalami akulturasi dengan budaya lokal Banten. Kesenian debus yang pada awalnya murni tarekat kini sudah bercampur bahkan terpisah dari tarekat itu sendiri. Kedua, Pergeseran dari segi pertunjukan, karena kalau dilihat pertunjukan debus sekarang kerapkali tidak menjalankan ritual sebelum bermain debus seperti yang diajarkan dalam tarekat, seperti pembacaan manaqib, pembacaan silsilah sebagai pendahuluan pertunjukan. Ini terjadi karena debus sudah mengalami pembaharuan (inovasi) sebagai sarana hiburan dan telah meninggalkan ajaran aslinya. Ketiga, Pergeseran dari segi perekrutan dan personil debus. Untuk bisa bermain debus, kita tidak lagi diharuskan untuk memasuki pada tarekat tertentu. Praktek debus bisa dilakukan tanpa masuk tarekat. Dengan demikian, para pemain debus, atau bahkan guru debus sekalipun tidak mesti atau bukan 
berarti ia orang tarekat. Tidak hanya itu, dilihat dari para pemain debus, ada di antaranya yang masih anak-anak. Keempat, dari segi tujuan debus. Pergeseran ini adalah sebuah kelanjutan dari adanya pergeseran debus dari segi ritualnya. Saat ini, meskipun padepokan debus tumbuh menjamur di mana-mana, tetapi semuanya lebih menekankan pada orientasi hiburan yang layak jual dan merupakan kebutuhan ekonomi bagi para pemainnya, sehingga kesenian debus saat ini telah mengalami perubahan yang signifikan. [ ]

\section{Daftar Pustaka}

Al-Abbas, Tb. Ismet, Sejarah dan Objek Spiritual Banten, Banten : Dinas Pendidikan, 1990.

Aceh, Abubakar, Pengantar Sejarah Sufi dan Tasawuf, Solo : Ramadhani,1989.

Bruinessen, Martin Van, Kitab Kuning, Pesantren dan Tarekat, Bandung: Mizan, 1999. Departemen Pendidikan dan Kebudayaan, Sejarah Daerah Jawa Barat, Jakarta : Balai Pustaka, 1997.

Djajadiningrat, Hoessein, Tinjauan Kritis tentang Sejarah Banten, Jakarta: Djambatan, 1981.

Hamka, Tasawuf: Perkembangan dan Pemurniannya, Jakarta: Yayasan Nurul Islam, 1980.

Mihrob, Halwani, “Fase, Dampak dan Perwujudan Dalam Budaya Islam ", dalam Aswab Mahasin (et.al ), Ruh dalam Budaya Bangsa, Jakarta : Festival Istiqlal II, 1996.

Nasution, Harun, Islam Ditinjau Dari Berbagai Aspeknya, Jakarta: UI Press, 1966.

Sutjianingsih, Sri, (peny.), Banten Kota Pelabuhan Jalan Sutra, Jakarta : Dirjen. Kebudayaan dan Sejarah Nilai-nilai Tradisional, 1995.

Yunus, Mahmud, Kamus Arab Indonesia, Jakarta: Hidayakarya Agung, 1989 . 